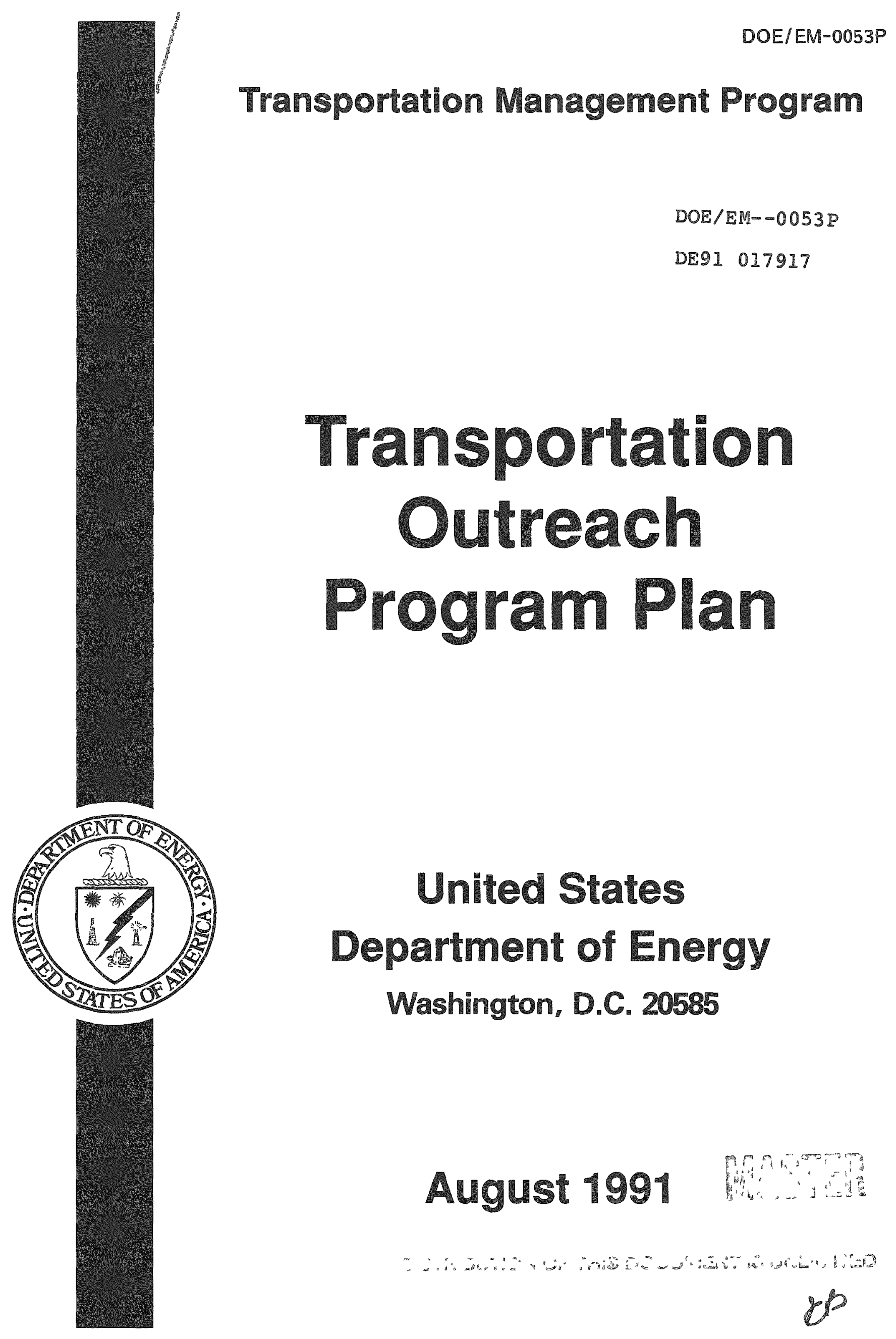




\section{DISCLAIMER}

This report was prepared as an account of work sponsored by an agency of the United States Government. Neither the United States Government nor any agency Thereof, nor any of their employees, makes any warranty, express or implied, or assumes any legal liability or responsibility for the accuracy, completeness, or usefulness of any information, apparatus, product, or process disclosed, or represents that its use would not infringe privately owned rights. Reference herein to any specific commercial product, process, or service by trade name, trademark, manufacturer, or otherwise does not necessarily constitute or imply its endorsement, recommendation, or favoring by the United States Government or any agency thereof. The views and opinions of authors expressed herein do not necessarily state or reflect those of the United States Government or any agency thereof. 


\section{DISCLAIMER}

Portions of this document may be illegible in electronic image products. Images are produced from the best available original document. 


\title{
TRANSPORTATION OUTREACH PROGRAM PLAN
}

\author{
FOREWORD
}

The Department of Energy (DOE) Transportation Management Program (TMP) is committed to providing opportunities for public interaction, working cooperatively with groups interested in or affected by DOE transportation, and providing information through the development and implementation of its Outreach Program. This Plan describes how the DOE plans to involve the public in its transportation programs.

This Transportation Outreach Program Plan will assist the Secretary of Energy in carrying out his vision of the "good neighbor" policy. The Department of Energy encourages face to face interaction and welcomes comments from everyone. Outreach means "to go beyond," and the TMP, through its Outreach Program, will hear and address the public's concerns and recommendations about transportation of hazardous and radioactive materials. The TMP Outreach Program is based on a commitment to two-way communication.

The TMP coordinates transportation policy for all DOE programs to ensure consistent approaches to transportation issues and operations. The TMP conducts outreach by interacting with many groups interested in DOE transportation, facilitating resolution of issues and information exchange, and coordinating the DOE's transportation emergency preparedness capabilities. Many of the specific activities in transportation outreach are usually carried out by field and area offices. 


\section{TABLE OF CONTENTS}

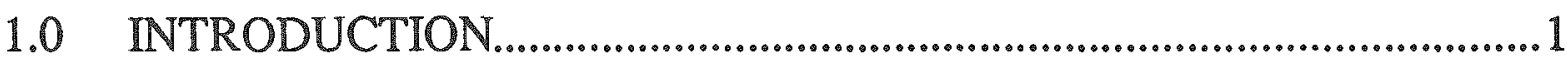

1.1 Overview........................................................................... 1

1.2 The Outreach Process .......................................................................2

1.3 Department of Energy Transportation.............................................2

1.4 Transportation Management Program

1.5 TMP Interactions with Other Department of

Energy Programs and Offices.....................................................6

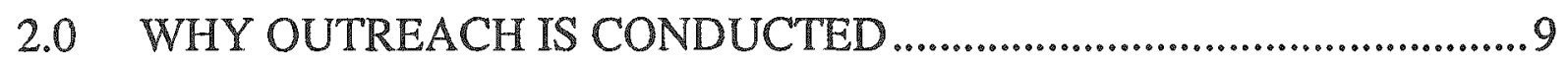

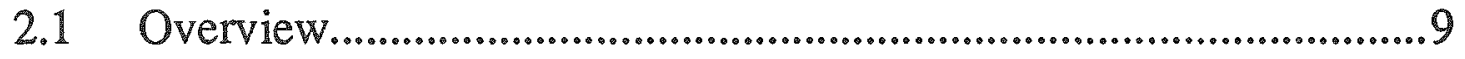

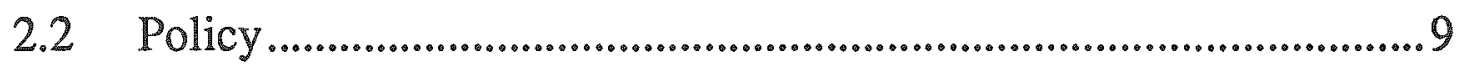

2.3 Public Input..............................................................................9

2.4 Public Concerns...................................................................... 10

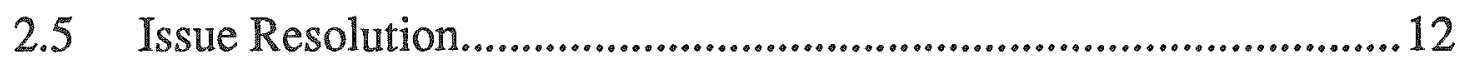

2.6 National Environmental Policy Act.............................................. 14

3.0 INTERACTIONS WITH THE INTERESTED AND

AFFECTED PUBLICS ............................................................... 16

3.1 Overview.................................................................................... 16

3.2 General Public......................................................................... 17

3.3 Other Federal Government Agencies ....................................... 18

3.4 State Governments................................................................. 19

3.5 Tribal Governments............................................................. 21

3.6 Local Government Organizations ..................................................21

3.7 Transportation Industry......................................................... 22

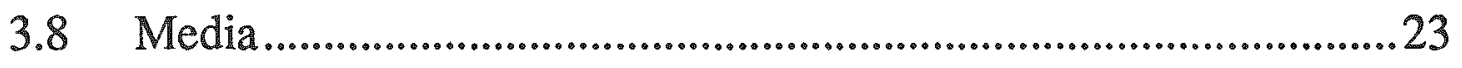

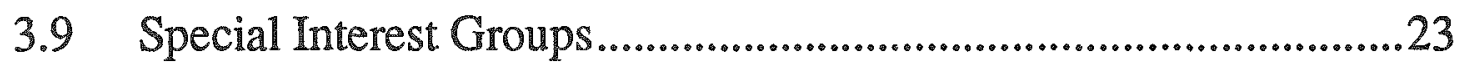

3.10 International Organizations.....................................................24 
4.0 PLANNED OUTREACH ACTIVITIES ..............................................25

4.1 Overview..................................................................................25

4.2 Transportation Assessment and Integration (TRAIN) Project .................................................................................25

4.3 Conferences, Meetings, and Workshops.........................................26

4.4 Training and Telecourses...............................................................27

4.5 Information Products and Activities ................................................28

5.0 CONCLUSION

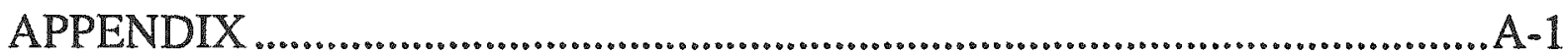




\section{LIST OF TABLES}

Table 1 The TMP Offers Risk Communication Training to Improve Two-Way Communication............................................ 12

Table 2 Fourteen Issues, Listed in Alphabetical Order, Identified Through Outreach ................................................................... 13

\section{LIST OF FIGURES}

Figure 1 Transportation Activities are Primarily Implemented Through Field and Area Offices.

Figure 2 The TMP is Assisted by DOE Headquarters Programs, DOE Field Organizations and Contractors

Figure 3 Outreach is Conducted With Interested, Affected Groups Involved in DOE Transportation 16

Figure 4 Successful Public Outreach and Involvement Requires a Two-Way Communication Process 


\section{TRANSPORTATION OUTREACH PROGRAM PLAN}

\subsection{INTRODUCTION}

\subsection{Overview}

The Department of Energy (DOE) Transportation Outreach Program aims to improve the dialogue between the DOE and the public, and to resolve issues concerning DOE-wide transportation policy. The DOE provides information about its programs to the public and encourages the public to voice their concerns regarding the safe transport of hazardous and radioactive materials. By becoming better informed about the viewpoints and insights of the public, the DOE is better equipped to resolve issues conceming DOE-wide transportation. As part of the "new culture" announced by the Secretary of Energy, new tools and attitudes are being applied to working with the public in an "open, forthright, consultative process." Outreach includes:

- Supporting opportunities for public interaction

- Working cooperatively with groups interested in or affected by DOE transportation

- Providing information about the DOE's transportation plans and activities

This Program Plan describes the DOE policies guiding transportation outreach efforts, the audiences at whom these efforts are directed, and the tools and products used to help in information exchange.

Transportation Outreach responsibilities reside with the Transportation Management Program (TMP), within the Office of Environmental Restoration and Waste Management. The TMP Outreach Program is nationwide in scope because DOE shipping routes are nationwide, crossing nearly every State, as well as Tribal lands. In addition to the TMP, three other DOE organizations have specific transportation outreach programs: the Waste Isolation Pilot Plant (WIPP) Project Office, the Office of Civilian Radioactive Waste Management (OCRWM), and the site-specific program at the Yucca Mountain Project Office. Coordination and interaction among these organizations is discussed in this Plan. 
Contact points for receiving transportation information from these and other programs are provided in the Appendix.

\subsection{The Outreach Process}

Transportation outreach is the means by which interested parties learn about and interact with the DOE regarding its shipping programs and activities.

Outreach is a two-way communication process that attempts to integrate the views of all parties. Understandable, timely, and consistent information is a critical link in the outreach process. It is important that interested parties be adequately informed to achieve an active and productive exchange. Because the numerous affected parties often have varying interests, consensus on issue resolution or alternative action is not always possible. Through an active and effective outreach program, however, a clear understanding of concerns and positions is often attainable.

An effective outreach program is planned well in advance and conducted in a timely manner. It involves the public in decision making, combines written and visual materials in a way that communicates clearly to the interested audiences, and uses feedback and evaluation techniques to ensure that information needs are being met. The TMP's Transportation Outreach Program is integrated with transportation operations, packaging and engineering activities to ensure accuracy of information and coordination of effort. Interested parties want to understand the basic elements of DOE transportation and packaging, including the safety measures taken during package design, construction, and transportation. Interested parties need to know their participation is a valued part of the program.

\subsection{Department of Energy Transportation}

The DOE is responsible for developing energy resources and supporting national defense activities. The agency's specific responsibilities include:

- Research in new energy technologies

- Conservation and development of renewable energy sources 
- Development of fossil and nuclear resources

- Assistance and research for energy conservation

- Production of nuclear materials for weapons

- Management of radioactive wastes

- Environmental restoration at DOE facilities or former sites

All of these activities include transportation of materials, ranging from business and industrial to radioactive and other hazardous cargoes. The DOE is committed to the safe, economical, and secure transportation of all its shipments. It has established a remarkable safety record. Radioactive material has been shipped for over 40 years without death or serious injury resulting from the radioactive nature of the cargo.

The DOE conducts all of its transportation and packaging operations within a well-defined regulatory structure. The DOE follows the pertinent regulations of the U.S. Department of Transportation (DOT), the U.S. Nuclear Regulatory Commission (NRC), the U.S. Environmental Protection Agency (EPA), and the Occupational Safety and Health Administration (OSHA).

The DOE transportation activities are directed from its Headquarters offices in Washington, D.C., and Germantown, Maryland, and are implemented through various field and area offices shown in Figure 1. At the field offices, traffic managers oversee shipping activities and provide a major communication link to Headquarters.

\subsection{Transportation Management Program (TMP) Responsibilities}

The TMP interacts closely with program-specific transportation offices, such as the OCRWM and the WIPP. The TMP also interacts with other program offices having transportation and packaging responsibilities, including Nuclear Energy; Defense Programs; Energy Research; Environment, Safety and Health; Public Affairs; and Congressional and Intergovemmental Affairs. 


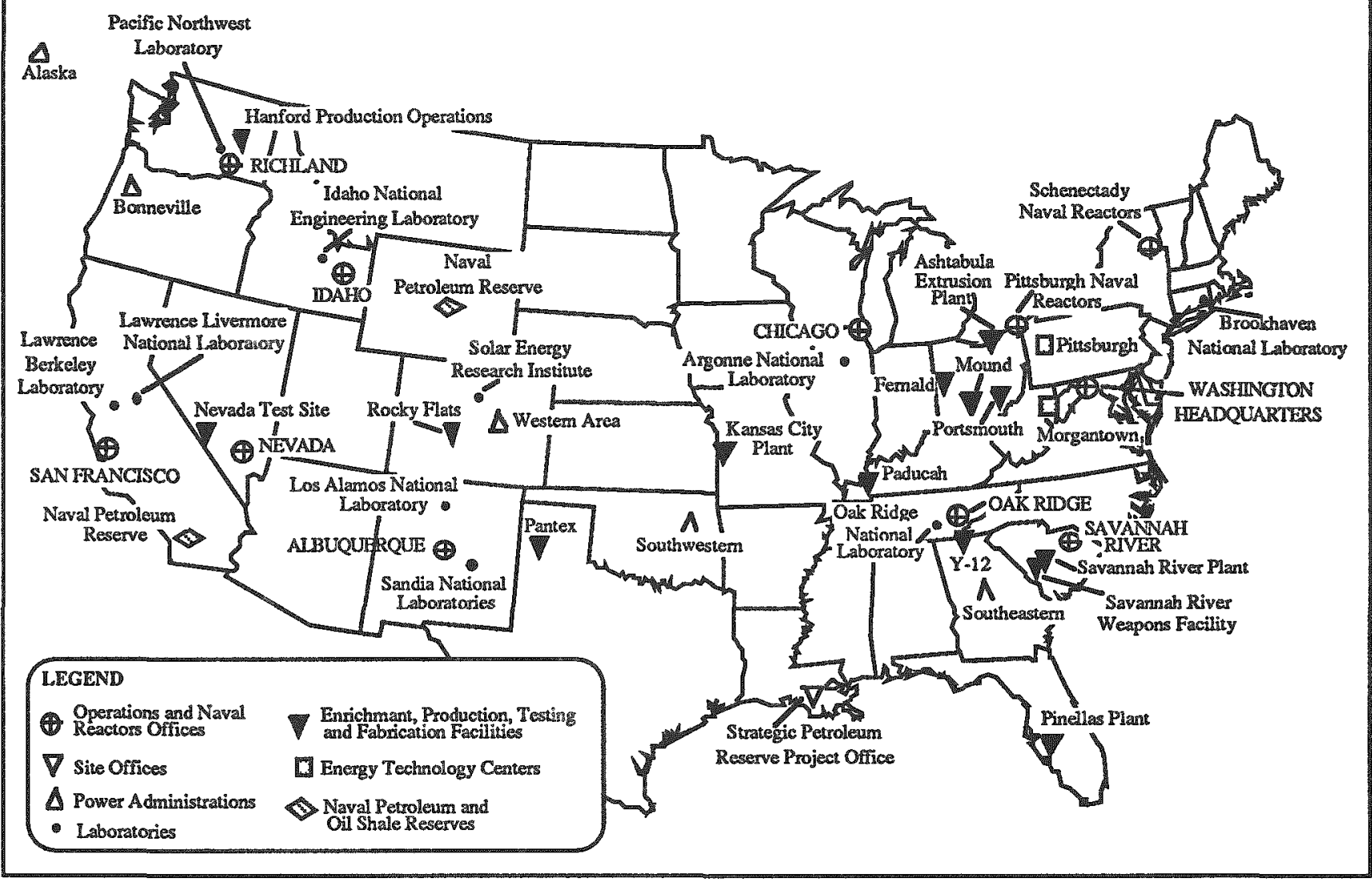

Figure 1. Transportation Activities are Primarily Implemented Through Field and Area Offices

The TMP includes three programs: (1) Transportation Technology, (2) Transportation Logistics, and (3) Transportation Outreach, which consists of Transportation Emergency Preparedness, Institutional, and Information and Communications. As shown in Figure 2, participating field offices and their laboratories and contractors support the TMP programs as follows: Albuquerque supports the Transportation Technology Program; Oak Ridge and Richland support the Transportation Logistics Program; Oak Ridge and Nevada support the Transportation Emergency Preparedness Program; Richland supports the Institutional Program and Oak Ridge, Richland and Chicago support the Information and Communications Program. The TMP is also assisted in all program areas by a management support contractor, Social \& Scientific Systems, Inc. 


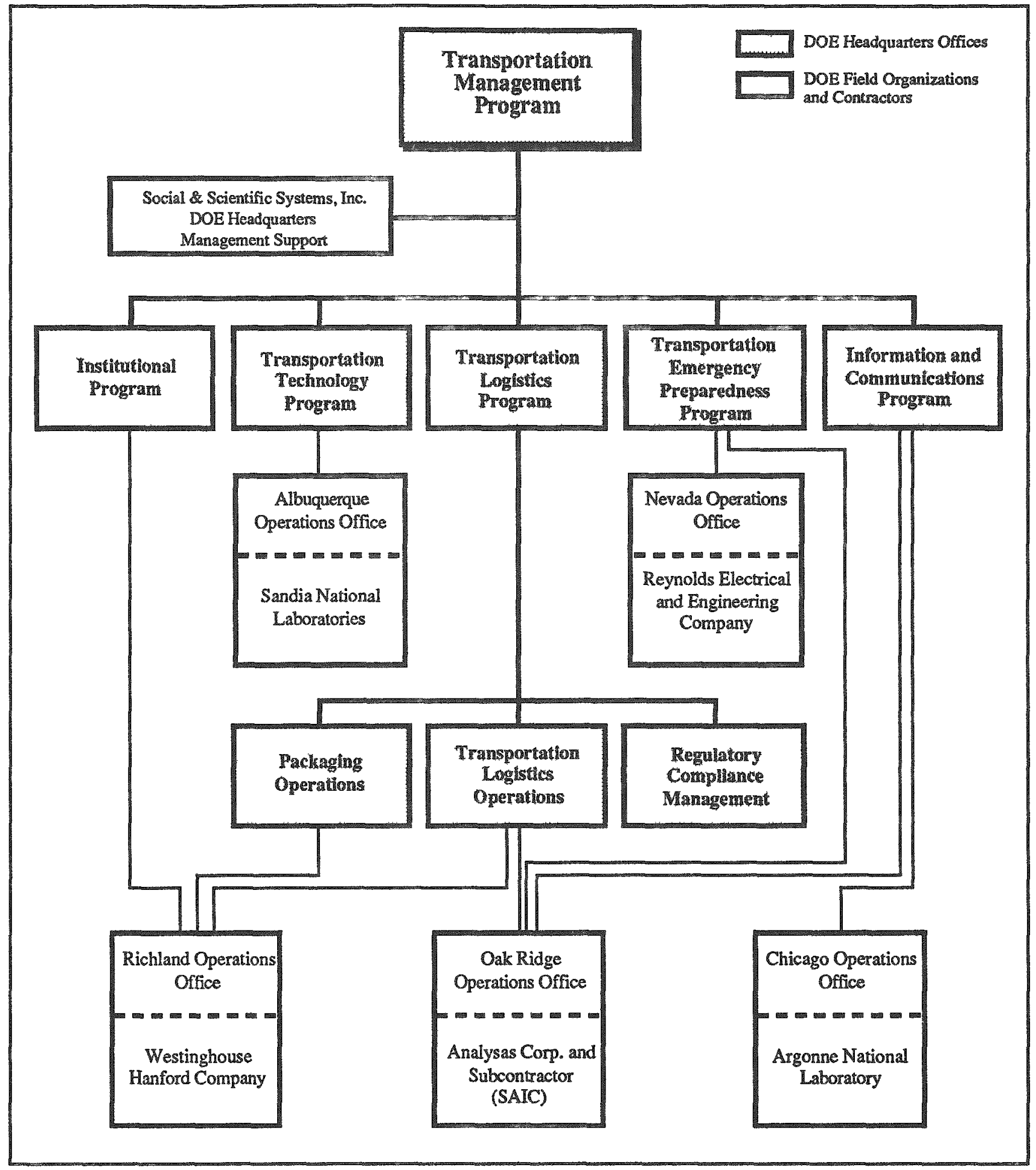

Figure 2. The TMP is Assisted by DOE Headquarters Programs, DOE Field Organizations and Contractors 
The Transportation Technology Program provides improved transport systems and packaging design through computer code development, research, safety assessment, package certification support, environmental risk analysis, materials evaluation, regulations and standards support, and package testing.

The Transportation Logistics Program supports day-to-day shipping activities, including development of more efficient systems, sponsoring personnel training, and conducting appraisals of the field operations for compliance with regulations and procedures.

Transportation Outreach supports all of the TMP's programs by interacting with the many groups interested in DOE transportation, facilitating resolution of issues, conducting or ensuring information exchange, and coordinating the DOE's Transportation Emergency Preparedness Program. The Outreach Activities identified in this Plan primarily are implemented through the TMP's Information and Communications Program and the Institutional Program.

The Transportation Emergency Preparedness Program was established to coordinate and focus the many transportation emergency preparedness capabilities and activities in the DOE. Coordination also takes place with States and Tribes who have voiced this issue to the TMP. This program will help to provide better assurance to State, Tribal, and local jurisdictions that the DOE's radioactive and other hazardous materials shipments will not be a threat to public health and safety or the environment. Affected parties must be assured that local emergency response capabilities are adequate, and that competent, well-planned Federal assistance is available as needed.

\subsection{TMP Interactions with Other Department of Energy Programs and Offices}

The TMP, in its oversight and policy coordination role, interacts with other DOE transportation organizations to resolve generic transportation issues for the DOE and ensure consistency in outreach policies. The DOE transportation issues are far reaching; they affect many States, Tribes, and local jurisdictions. To resolve them, the TMP works closely with DOE field and project offices and 
other DOE programs. The TMP also coordinates external interactions with the Office of Public Affairs, which is responsible for ensuring consistent and integrated outreach policies for the DOE programs.

Many outreach activities are carried out by the field offices and site operations. These offices deliver DOE transportation messages and provide interactive opportunities with their specific publics. In the field, outreach is conducted by traffic managers and other transportation program employees, as well as through public affairs and institutional specialists. This may include making presentations for civic and local govemment organizations and providing information to the public. The TMP provides information resources to support these efforts.

The TMP chairs a Transportation Institutional Task Force. Members include DOE Headquarters and field office representatives from various $D O E$ transportation programs, primarily OCRWM and WIPP, with invited participation of contractor support personnel and external groups or organizations, as appropriate. The goals of the Task Force include the exchange of experiences and insights, discussion of issues and concerns common to DOEwide transportation, identification of activities to ensure consistency and avoid duplication, exchange of draft documents for review and comment, identification of opportunities for dialogue, and prioritization of issues to be analyzed. Special committees address issues or activities that require further study, analysis, and cooperative resolution among the transportation programs.

The TMP provides transportation perspectives and information to facilitate and support the opening of WIPP for limited acceptance of transuranic waste during a test phase. This facility will receive transuranic waste from DOE facilities throughout the country if a favorable decision is made at the end of the test phase. As such, the TMP chairs a transportation-specific effort, the WIPP Transportation Task Force, to ensure productive interactions with the corridor States and Indian Tribes along the routes to WIPP. The DOE has entered into cooperative agreements with regional organizations that will administer funding to, and coordinate activities of, corridor States. Plans are under development for implementing cooperative agreements directly with Tribal governments to address WIPP transportation issues. 
The TMP has also participated in a Task Force for development of the Environmental Restoration and Waste Management Five-Year Plan. An important outreach function of the Task Force was development of a process for review and comment on the Plan by a State and Tribal Government Working Group. Another function of the Task Force was to formulate the mechanism for community involvement in Environmental Restoration and Waste Management activities. The TMP is participating in a national exhibit tour to explain plans for environmental restoration and waste management at DOE sites. 


\subsection{WHY OUTREACH IS CONDUCTED}

\subsection{Overview}

The DOE policy prescribes, and experience proves, that for any plan to go forward in the public domain, an understanding of issues and concerns must be developed.

The Transportation Management Program (TMP) emphasizes openness in conducting its programs, and wants the public to have the opportunity to participate in the decision-making process as the DOE develops and implements its nationwide cleanup efforts. The DOE will listen to its critics as well as its supporters and respond by demonstrating its commitment through action.

\subsection{Policy}

The Transportation Outreach Program implements DOE policies, encouraging "greater public understanding of our national energy plans, policies, programs, resources, and technical options through dissemination of reliable information" (DOE Order 1350.1, "Audiovisual and Exhibits Management"). It is directed "to effectively originate, coordinate, produce, distribute, and inventory publications appropriately describing the DOE's activities" (DOE Order 1340.1A, "Management of Public Communications Publications, and Scientific, Technical and Engineering Publications.") All transportation-specific outreach will be consistent with the policies and directives of the DOE's Office of Public Affairs.

\subsection{Public Input}

The TMP values external involvement in DOE program planning. Interested groups often have insights and information that can lead to better procedures or methods of conducting the business of DOE transportation. Outreach provides a means of identifying issues, concerns, and possible solutions from the perspectives of interested individuals and groups. 
Public involvement will be needed for the transport of radioactive, hazardous and mixed waste as part of the extensive cleanup and disposal activities planned for DOE production and research facilities. The DOE is regulated by the Environmental Protection Agency (EPA) and will follow the Resource Conservation and Recovery Act and other environmental regulatory requirements. Individual $\mathrm{DOE}$ field offices are developing community relations plans that provide for public participation. Each site will conduct a feasibility study describing alternatives for cleanup, some of which may involve transportation. The TMP plans to follow these activities and provide assistance as needed regarding transportation.

\subsection{Public Concerns}

Despite the DOE's excellent transportation safety record, interested members of the public continue to present concerns regarding environmental, health, and safety consequences of hazardous and radioactive materials shipments. The TMP acknowledges that one of the public's concerns is that the DOE maintain continued commitment to safety and vigilance over these shipments.

In order to address public concerns, it is important to gain an understanding of public perceptions of the transportation program and its proposed activities. This requires open communication, interaction, and research into the issues that concern the public. The DOE accomplishes this by attending public meetings, reading and reviewing publications, and conducting interviews and surveys. The Transportation Outreach Program will be attentive to public perceptions about the process the DOE uses to implement its transportation program, to public perceptions of the risks associated with transportation, as well as the DOE's trustworthiness and ability to manage the risks.

Considerable research on perceptions of risk has shown that the process by which decisions are made, and the credibility and trustworthiness of the people and organizations involved, affect the perceptions of risk. It is well documented that many of the affected and interested parties perceive the risks of transporting radioactive materials to be sufficient to warrant concem, despite extensive documentation by government and industry risk assessment specialists that the 
probability of harmful accidents is very low. Nevertheless, the public's concern about all types of radioactive substances has created a significant barrier to acceptance of radioactive materials transportation, and must be addressed by the Transportation Outreach Program.

Research has found the following to be important in effective risk communication:

- Accepting and involving the public as a legitimate partner in the design, evaluation, and monitoring of the program

- Maintaining honest, frank, and open communication with the interested and affected public

- Listening, hearing, and responding to the public's specific concerns

- Coordinating and collaborating with knowledgeable and credible sources

- Effectively interacting with the media

- Ensuring any information communicated is backed up by actions taken

The Transportation Outreach Program Plan has been designed to reflect the lessons learned in this research. In addition, the Transportation Outreach Program recognizes the need to demonstrate good management, careful planning, and commitment to evaluation, review, and improvement. The TMP is actively incorporating these principles into its Transportation Outreach Program, and is offering training to improve the communication skills of its staff. The TMP has conducted risk communication training classes for DOE and DOE contractor personnel, and has recently co-hosted a risk communication workshop with the Western Governors' Association. This workshop involved the WIPP corridor States, WIPP transportation personnel, shipping site representatives, and TMP staff. The TMP plans to continue offering risk communication training in upcoming years, as shown in Table 1 . 
Table 1. The TMP Offers Risk Communication Training to Improve TwoWay Communication

\section{Risk Communication Training}

- TMP and Contractor Staff

- TMP Spent Fuel Cask Mock-Up Exhibit

- WIPP/Western Governors' Association

- Other Transportation Program Offices

- Follow-Up Training, TMP \& Contractor Staff

- Field Office Transportation Staff
FY 1990 Completed

FY 1990 Completed

FY 1991 Completed

FY 1991

FY 1992

FY 1992

\subsection{Issue Resolution}

Issues are best resolved in a cooperative manner, and the TMP is committed to issue resolution whenever possible. Issue resolution involves identifying and addressing those concerns in a responsive manner. It should be recognized that resolution of issues to all parties' satisfaction may not always be possible.

The Issue Identification Process: Issues are identified through network meetings, workshops, conferences, as well as input from the field office traffic managers, the DOE's Transportation Institutional Task Force, other DOE programs, and the entire array of interested and affected parties discussed in Section 3. The TMP also identifies issues through concerns raised in media articles concerning transportation events, campaigns, legislative actions, transportation studies, and public comment. Less routine means of issue identification include letters, phone calls and feedback from participants in DOE transportation regulations training programs. Table 2 shows the institutional 
issues associated with DOE transportation activities that have been identified through the Outreach Program thus far. Additional issues will be added to the list as they are identified through continuing outreach activities.

Table 2. Fourteen Issues, Listed in Alphabetical Order, Identified Through Outreach

\section{Institutional Issues Being Considered by the $\mathbf{D O E}$}

- Carrier Qualification

- Emergency Preparedness and Response

- Human Factors

- Incident Experience

- Involvement (State, Tribal and Local) in DOE Programs

- Liability

- NEPA Requirements

- Packaging Design

- Pre-Notification of Radiological Materials Shipments

- Quality Control of Radioactive Material Packagings

- Risk in Radioactive Materials Transportation

- Routing of Shipments

- State Inspections, Fees and Permits

- WIPP Shipments

The Issue Analysis Process: Once issues have been identified, additional information is gathered to allow the Outreach Program to analyze:

- How the issue is defined by various interested and affected parties, as well as the various DOE programs

- Who has responsibility for resolving the issue

- How affected parties like to see the issue resolved

- How all parties' interests are affected by altemative issue resolution strategies 
Transportation institutional issues are complicated and involve a number of interested and affected parties, as mentioned in Section 3.0. As a result, issue analysis blends into issue resolution, as gathering information needed for issue analysis overlaps with identifying issue resolution strategies.

The Issue Resolution Process: The issue resolution process actually starts with the outreach activities used to define and analyze the issues. In developing a strategy for resolution, priority is given to issues that have been raised frequently and that have impact on the DOE's programs. The issue resolution process requires interaction with the various groups that are affected by the issue. This frequently means that issue resolution must be coordinated with a large number of affected parties, including the general public, other Federal agencies, States, Tribes, and local governments. Every effort is made to address the interests and concerns of each of the affected groups and to seek solutions acceptable to all affected groups. Nevertheless, the DOE recognizes that establishing consensus among all parties, though desirable, is not always possible.

Coordination within the TMP's transportation operations and research development activities, and through the Transportation Institutional Task Force, ensures that input from affected groups is incorporated into the resolution process, and that the DOE develops a consistent resolution strategy. A systematic, open approach helps to integrate the various interests and alternatives. This process is supported by the development and distribution of information products that are factual, consistent and address the public's concern regarding hazardous material transportation and the DOE's ability to manage risk. This open approach also promotes understanding of the DOE's transportation activities. The public must understand the complexity of the issues to effectively participate in the decisions required to resolve them.

\subsection{National Environmental Policy Act}

The National Environmental Policy Act (NEPA) requires the DOE to document that it has carefully examined all actions, including those related to transportation, to determine whether they will result in any significant 
environmental impacts. The first step in making such a determination is through development of an Environmental Assessment (EA). An EA may either result in a finding of no significant impact (FONSI), or require the DOE to proceed on to the next step in the NEPA process, which is the preparation of an Environmental Impact Statement (EIS). An important part of preparing an EIS is the DOE's solicitation of public input regarding the scope of the documentation. This involves finding out what issues interested members of the public feel are important, and need to be analyzed. The TMP carefully plans its public involvement activities to assure that "scoping" the EIS occurs as early as practical, and in a manner that is responsive to public comment. Information products are designed and made available to the public to help interested parties take part in scoping activities in an informed and effective manner. Public hearings and comments also reflect on how adequately an EIS addresses potential impacts. Currently, the DOE relies on the Final Environmental Impact Statement on the Transportation of Radioactive Materials by Air and Other Modes (NUREG0170) as documentation of general transportation issues, and conducts programspecific environmental documentation as needed. 


\subsection{INTERACTIONS WITH THE INTERESTED AND AFFECTED PUBLICS}

\subsection{Overview}

As shown in Figure 3, the Transportation Management Program (TMP) conducts outreach with the general public and a wide variety of organizations and groups:

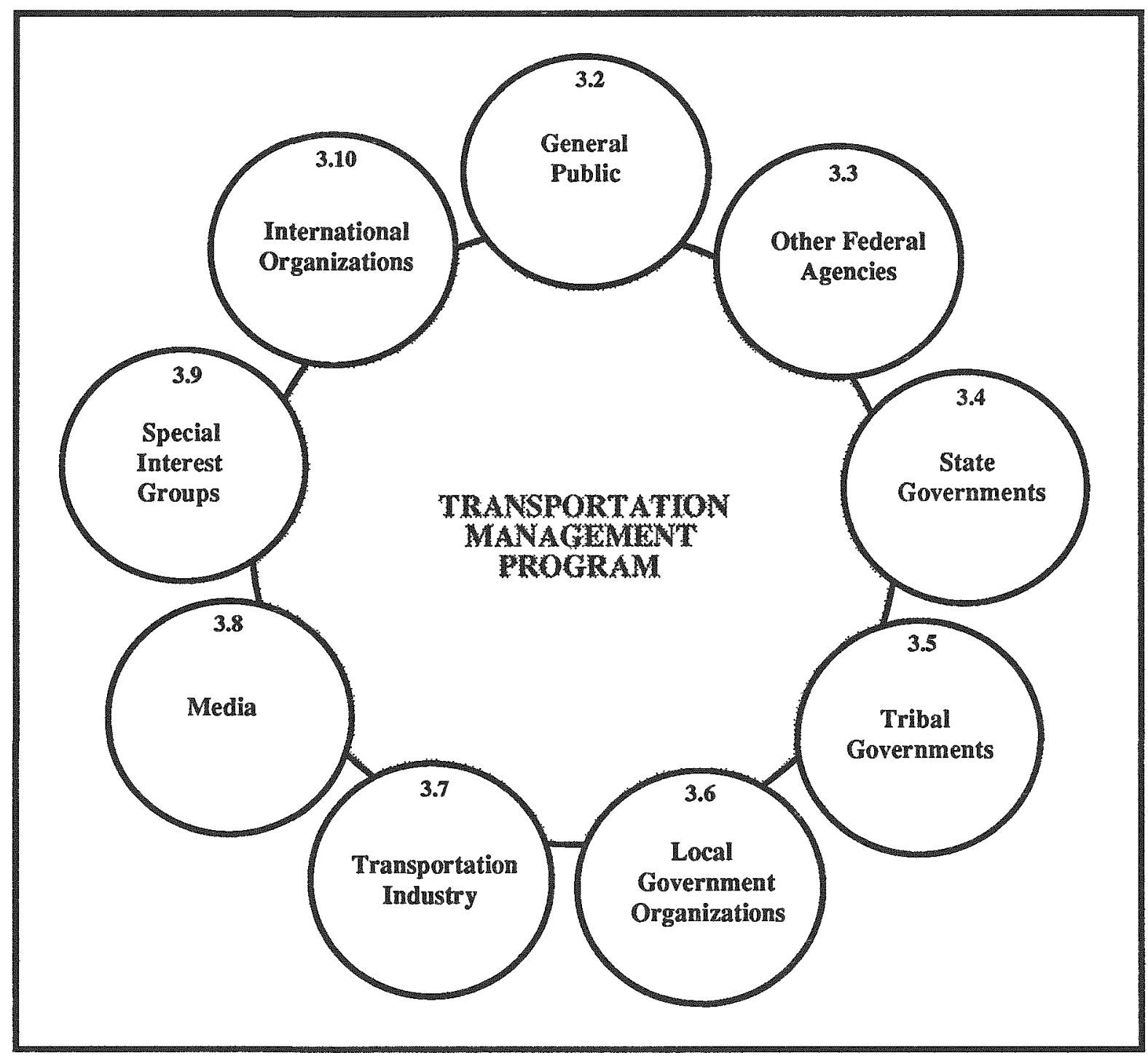

Figure 3. Outreach is Conducted With Interested, Affected Groups Involved in DOE Transportation 
The type and frequency of interaction vary according to the needs, interests, and activities of the participants. Because the types of interactions and level of interest varies with the group, issue, and activity, outreach is tailored to the particular needs of the parties involved. Efforts are focused on interacting with representative groups as much as possible.

The principal means of interaction include:

- Meetings, workshops and conferences to exchange technical and institutional information on new development in areas pertinent to the DOE's shipping activities, as well as formulation of methods of coping with transportation issues and problems

- Training and telecourses for emergency preparedness and response, Federal shipping and packaging regulations, and basic aspects of shipping radioactive materials

- Information products including factsheets, booklets, exhibits, and videos, limited copies of which are available on request at no charge

\subsection{General Public}

It is important that citizens have access to accurate information about governmental programs. The TMP Outreach Program seeks to provide both information and access to the decision-making process to the general public. Although the interests of the general public are often represented by other organizations and groups (Federal agencies, State, Tribal, and local governments, the media, and special interest groups), the TMP Outreach Program also provides a direct link to individual members of the public.

Outreach with the general public focuses principally in two areas:

(1) providing information products that show or describe transportation-related topics and TMP program activities, and (2) responding to comments or questions received from members of the general public about DOE transportation programs. The Outreach Program seeks to provide attractive opportunities for information exchange and interactive communication with the general public 
through activities such as staffed exhibits, displayed at DOE facilities" "open houses" or national conferences, and the production and distribution of printed materials and videos. The TMP receives input, feedback, and direction from the public, either formally through scoping meetings, public hearings, and written comments; or informally, through phone calls, meetings, conferences, or conversations. These inputs are responded to and incorporated into the program.

\subsection{Other Federal Government Agencies}

The TMP interacts primarily with four Federal agencies: the Department of Transportation (DOT), the Nuclear Regulatory Commission (NRC), the Environmental Protection Agency (EPA), and the Federal Emergency Management Agency (FEMA). Interactions with Congress are generally limited to responding to Congressional inquiries and preparing information for DOE management to present to Congress and its committees.

U.S. Department of Transportation: The DOT has primary responsibility for regulating safety in transporting all commodities, including hazardous and radioactive materials. The DOT regulates shippers (including the DOE) and carriers, and sets design requirements and test conditions for packages carrying radioactive material. The test conditions become more stringent as the level of radioactivity of the contents increases. The DOT reviews and comments on appropriate TMP documents. Conversely, the TMP provides input to prepare proposed DOT rulemakings, which, if finalized, would change transportation regulations.

U.S. Nuclear Regulatory Commission: The TMP interacts with the $\mathrm{NRC}$ in the areas of packaging standards and designs. The NRC regulates the packaging and transport of radioactive material for its licensees and commercial shippers. Under agreement with the DOT, the NRC sets the standards for packages. While the DOE has the authority to certify that its packages meet the required standards, the trend over the past several years has been to obtain NRC certification. This is a move toward uniformity in Federal compliance practices. 
U.S. Environmental Protection Agency: The shipper is responsible for cleanup and long-term safety, should a transportation accident involving radiological materials occur. The EPA may provide personnel, equipment, and laboratory support to the DOE during the initial phase of accident response. The EPA would then assume intermediate and long-term responsibility from the DOE for coordinating radiological monitoring and assessment.

Federal Emergency Management Agency: The DOE coordinates with the FEMA on planning for Federal assistance and response to radioactive materials incidents. The Federal Radiological Emergency Response Plan, the integrated plan coordinating all Federally-provided radiological assistance, assigns a lead role to the DOE for providing assistance to State and local first responders in the areas of radiological assessment and mitigation. The Plan was developed by the FEMA in conjunction with 11 other Federal agencies, including the DOE. Information about this plan, as well as a description of the DOE's comprehensive capabilities and resources for responding to radiological transportation emergencies, may be found in a report entitled, "Emergency Preparedness For Transportation Incidents Involving Radioactive Materials," (SAIC-89/1354, updated 5/90).

The DOE also complies with the applicable regulations of the Postal Service, the General Services Administration, the Coast Guard, the Interstate Commerce Commission, the Department of Commerce, the Bureau of Customs, and the Occupational Safety and Health Administration. Interactions usually involve information exchange, as well as regulatory interpretations and clarification.

\subsection{State Governments}

Because DOE shipping occurs in almost all 50 States, it is imperative to maintain and expand interactive relationships with State government representatives. State and local officials have responsibility for first response to transportation accidents. When the DOE transports certain shipments of nuclear waste and spent fuel, it provides advance, written notification to the Governors or designated officials of the States through which the shipments move. The DOE 
and other Federal agencies provide guidance and support to State and local emergency responders through information on topics such as assignment of responsibility, prompt communication among principal response organizations and emergency personnel, provision of radiological monitoring and recovery services upon request, and preparation and distribution of timely public information. In addition, the DOE supports a variety of emergency response training activities for State personnel.

States also have the authority to designate routes for highway routecontrolled quantity shipments. Although the DOT regulations establish specific, preferred routes for highway route-controlled quantity shipments (those with high levels of radioactivity), State routing agencies may designate alternate routes, following the DOT guidelines. The State must justify an alternate route designation with a routing analysis and record it with the DOT. Before a route selection is made final, the State routing authority must consult with affected local jurisdictions and neighboring States to ensure that all factors have been considered and that their designated route will "match up" with the DOT preferred routes at State borders.

Consequently, States along the routes of DOE shipments share many interests and concerns about transportation issues. Because of this commonality, resolution of transportation issues may require cooperative action. The TMP interacts not only with individual States where DOE facilities are located or through which DOE shipments will pass, but also with organizations that represent multiple States along DOE shipping routes. The Western Governors' Association and the Southern States Energy Board are examples of these multiState organizations.

The WIPP Project Office of the DOE has entered into a cooperative agreement with the Western Governors' Association to administer funding to the ten western States through which DOE shipments of transuranic waste to WIPP will occur. The TMP serves as the policy lead in this cooperative agreement. In 1989, the Western Governors' Association submitted a "Report to Congress" outlining concerns about transportation to WIPP, and made recommendations for cooperative work between the Federal government and western corridor States. The Report identifies accident prevention, emergency response, and public 
education as major areas of concern. The WGA-WIPP cooperative agreement extends involvement with the western States to work on resolving these issues.

The DOE is working toward the establishment of a similar cooperative agreement with the Southern States Energy Board. This agreement will administer funding to the ten southern States and three central States that will be affected by WIPP shipments.

\subsection{Tribal Governments}

The Federal government has a special trust responsibility to Tribal governments, meaning the Federal government is obligated to protect the interests of Tribes, including their right to self-government and their pursuit of economic development and resource management goals. The TMP recognizes its responsibilities concerning Federal trust relations, Indian laws, and sovereignty issues. A formal, DOE-wide policy for interacting with Indian Nations is currently under development by the DOE Office of Intergovernmental Affairs and Public Liaison. Ongoing outreach is conducted with the Indian Nations whose reservation lands are crossed by shipments to WIPP. Issues identified by this outreach effort include transportation safety and Tribal emergency preparedness, including intergovernmental, economic, and cultural impacts, as well as overall Tribal policy regarding interactions. Cooperative agreements are being planned with these Tribal governments. The DOE will meet with the other potentially affected Tribes, as appropriate.

\subsection{Local Govermment Organizations}

Local governments are important participants in the DOE transportation program. Interaction with local governments is often done at the field office level, with reliance on public affairs and traffic manager contacts. The DOE also has introduced local government outreach through a cooperative agreement with the Urban Energy and Transportation Corporation (UETC), a non-profit organization whose Board of Directors is made up of local and State government representatives. 
Since 1987, the UETC has conducted a series of workshops, presentations, and interactions statewide to promote communications with urban officials on transportation policies and programmatic issues. Other activities include municipal league meetings, production of a newsletter and establishment of a computer bulletin board. Primary areas of concern are accident prevention, emergency preparedness, and public information. While the focus of the UETC cooperative agreement will remain on urban areas, the TMP will foster an interjurisdictional approach to the resolution of transportation issues by including some State and Tribal participation in the regional workshops.

The TMP offers regional training courses to State and local personnel on hazardous materials identification, transportation regulations, and emergency response principles. Further discussion of training courses can be found in Section 4.4.

\subsection{Transportation Industry}

The rail, highway, air, and water carriers are essential partners in the DOE's transportation activities. Many issues and concerns raised by the interested public focus on safe operation by the transportation industry. Close working relationships exist with commercial carriers who transport DOE materials. These relationships are maintained through the DOE field and area office traffic managers. The DOE has contacts with nationwide transportation associations, such as the Association of American Railroads, American Trucking Association and other carrier organizations representing the industry. The DOE also interacts with packaging designers and manufacturers at meetings, workshops, and conferences.

In March 1990, the TMP facilitated a Transportation Roundtable meeting in Washington, D.C. at which participants discussed regulatory, technical, and institutional issues and trends affecting transportation policy and programs. Participants included representatives from Federal agencies, members of the industry, public involvement groups (such as the League of Women Voters), and the technical media. This was the first in a series of roundtable meetings to 
encourage interaction with individuals outside of the DOE and groups concerning Environmental Restoration and Waste Management activities.

\subsection{Media}

To provide a single, focused voice with the news media, the Secretary of Energy created a new Office of Public Affairs. As of June 1990, all DOE Headquarters program organizations' public relations and public information functions were transferred to the Office of Public Affairs.

The TMP's media interactions are coordinated through the Headquarters Office of Environmental Restoration and Waste Management media representative, and the Office of Public Affairs. When the TMP receives a request for information from the media, it is generally referred to the Environmental Restoration and Waste Management representative. The TMP prepares materials for press releases issued by the Office of Public Affairs. The TMP's Transportation Outreach Program will make information available for the media through informational packets and background material, such as written text, video clips, or photos specific to a situation or question.

All press information documents or press releases relating to the activities of the TMP will be prepared by Office of Public Affairs staff. Likewise, all interactions with the news media are to be coordinated with the Office of Public Affairs, according to Secretary of Energy Notice 6B-90, issued in August 1990. This new, centralized system for managing public affairs activities is part of a coordinated effort to improve the DOE's ability to respond to and anticipate public involvement and interest.

\subsection{Special Interest Groups}

Organizations represent various segments of the public's specific interests on environmental, safety, and health issues. These organizations are often comprised of volunteers and active participants in public involvement programs. The TMP interacts with these groups by providing information on request and 
receiving input through correspondence and phone calls. Interactions generally occur in specific situations, such as during NEPA implementation.

\subsection{International Organizations}

The International Atomic Energy Agency provides regulatory guidelines which serve as the basis for international shipments of radioactive materials. The TMP reviews and comments on the International Atomic Energy Agency's proposed regulatory changes, and participates in all international exchanges of technology developments. In cooperation with the International Atomic Energy Agency, the TMP hosted the ninth International Symposium on Packaging and Transportation of Radioactive Materials (PATRAM) in Washington, D.C., in June 1989. With more than 600 attendees from 17 countries, PATRAM ' 89 represented a major interactive event in the field of radioactive materials transportation. The TMP expects to play a strong supporting role in PATRAM '92, which will be held in Tokyo, Japan.

The TMP also complies with the rules and regulations of the International Civil Aviation Organization, International Air Transport Association, and the International Maritime Organization. For special international shipments requiring specific international agreements, the TMP interacts with the State Department. 


\subsection{PLANNED OUTREACH ACTIVITIES}

\subsection{Overview}

To better anticipate the need for public information and outreach activities, the Outreach Program is taking part in a system-wide Transportation Assessment and Integration Project, or TRAIN. Planned outreach activities will be shaped, in large part, by the results of the TRAIN Project. Ongoing plans call for continued sponsorship and participation in meetings and workshops, organizing and conducting training and telecourses, and preparing, distributing and evaluating information products.

\subsection{Transportation Assessment and Integration (TRAIN) Project}

Important changes in DOE organization, policies and management philosophy have taken place in recent years. Program emphasis has also changed toward waste storage, treatment and disposal; site cleanup and restoration; and modernization of the production complex. The TMP is evaluating its organization and programs to determine what actions are necessary to ensure that it is responsive to transportation and packaging needs in the 1990s. The Transportation Assessment and Integration (TRAIN) Project was established to perform this assessment. The TRAIN project will explore how to better support the transportation program and field offices as well as coordinate with the Environmental Restoration and Waste Management Five Year Plan and community relations activities associated with environmental restoration and cleanup. Outside input and review is critical for new insights, lessons learned and new developments in public information and involvement. Two workshops will be conducted involving representatives from States, Tribes, industry, and other DOE and Federal programs. The first will be a fact-finding session to determine the scope of the review, and the second will be a check on progress and direction. 
Planned 1991 TRAIN activities include:

- Fact-Finding Workshop

- Preliminary Review Workshop

- Final Report
May 1991

September 1991

December 1991

\subsection{Conferences, Meetings, and Workshops}

The TMP routinely participates in national and international conferences to exchange technical and institutional information on new developments in areas pertinent to the DOE's shipping activities, as well as formulation of methods of coping with transportation issues and problems. One focus of participation is the annual Waste Management Conference held in Tucson, Arizona, sponsored by The University of Arizona, College of Engineering and Mines; American Society of Mechanical Engineers; the Arizona Section of the American Nuclear Society; and the U.S. Department of Energy. At this conference, the TMP sponsors sessions on transportation. As mentioned earlier, another conference that TMP actively participates in is the International Symposium on Packaging and Transportation of Radioactive Materials (PATRAM).

The Western Governors' Association WIPP Transport Technical Group meets with DOE four or more times every year. These meetings provide information and reports on progress of activities identified in the WGA/DOE cooperative agreements. Lead States have been identified to address specific issues in detail. Examples include safe parking, bad weather protocols, and public information. Recommendations from this group will help the DOE improve WIPP transportation safety. The Southern States Energy Board also holds quarterly meetings, at which WIPP transportation issues are discussed. It is anticipated that several meetings regarding WIPP transportation will take place annually with Tribal governments as well.

As discussed earlier, the Urban Energy Transportation Corporation (UETC) facilitates workshops with local government officials and the TMP. Meeting representatives include over 150 senior local government officials, such as mayors, council members, and city managers. Also included are fire and 
police chiefs, directors of emergency and environmental management programs, and other officials concerned about issues related to hazardous materials transportation. UETC workshops provide valuable information for the development of a safer transportation program. UETC activities have included:

- A workshop on WIPP for local government officials from WIPP corridor jurisdictions, including the presidents of seven State municipal leagues

- A national conference with over 125 representatives from five Federal agencies, seven States, and over 40 cities and counties

- A presentation by the TMP Director at both the Colorado Municipal League Meeting and a meeting with over 20 elected officials from jurisdictions near DOE facilities or transportation routes

Planned TMP participation in conferences, meetings, and workshops include:

- Waste Management Conference, Tucson, Arizona: Annually

- PATRAM: Every three years

- Western Governors' Association WIPP Transportation Group: Four or more meetings per year

- Southern States Energy Board: Two or more meetings per year

- Tribal Governments: Two or more meetings per year

- Urban Energy Transportation Corporation Local Government Workshops: Two or more meetings per year

\subsection{Training and Telecourses}

The DOE supports a variety of training activities for both internal and nonDOE participants. A one-day course for the DOE and for State and local emergency responders serves as a basic orientation to emergency situations involving the transport of hazardous materials, and particularly radioactive materials. The course provides participants with an understanding of shipping 
requirements so they can determine the material present, the hazard involved, and the correct mitigation procedures.

A basic four-day course on the Federal regulations regarding the shipment of radioactive materials is also offered, at which the DOE trains its employees and contractors to comply with all applicable Federal regulations. When space is available, the DOE also offers training courses to interested parties, such as representatives from commercial carriers, State and local public safety and enforcement agencies, and other government employees.

The TMP also cooperatively participates in special training activities, such as telecourses. One example is a telecourse which was broadcast in the summer of 1989 in cooperation with the FEMA and the DOT regarding first response to transportation emergencies involving radioactive materials. The broadcast had a potential viewing audience of approximately 100,000 fire prevention, emergency response, law enforcement, and public service personnel on the FEMA's Emergency Education Network. It featured a learning exercise as well as viewer call-in opportunities. The telecourse received first place for the "Best Distance Learning Program in the Area of Continuing Education" at the 8th Annual Telecon Awards Ceremony during the Telecon IX Exposition, a competition that included corporations, government agencies and educators. As a result of its success, the TMP is planning another telecourse for late 1991. Upcoming training and telecourses include:

- First Response

Two courses annually

- Radioactive Materials Transportation Basic Eight workshops annually

- FEMA/DOT/DOE One course planned in 1991

\subsection{Information Products and Activities}

Developing and disseminating understandable information about the TMP is an integral component of an effective, open, interactive Outreach Program. It is a means for improving the quality of the information exchange process and the relationship among participants. A successful public information program provides opportunities to read, see, hear, and ask questions about the technical 
aspects of the program through a variety of written materials and audiovisuals. Many of the information tools and activities, such as the exhibit displays, involve interactions with the affected and interested parties. These interactive methods facilitate communication between the DOE and the public. Planned exhibit showings for 1991 include:

- Waste Management '91 Technical Exhibition Tucson, AZ: February 1991

- Transportation Management Workshop Rockville, MD: March 1991

- University of Wisconsin Engineering Expo Madison, WI: April 1991

- U.S. Jaycees Annual Meeting Minneapolis, MN: June 1991

- International City Management Association Annual Meeting and Exposition (ICMA) Boston, MA: September 1991

The TMP's information products include factsheets, booklets, exhibits, and videos. Factsheets provide a snapshot of information about a particular topic. Booklets provide an in-depth look at transportation topics. Technical reports on specific transportation subjects or issues are also developed. Exhibits and models provide an overview of transportation information and an opportunity for the viewer to interact with a TMP representative and obtain printed materials. Audiovisuals include slides, videos, and films. Slides provide a flexible format for tailoring presentations, while videos, films, and video games provide entertaining opportunities for a more focused look at a particular topic.

Plans are underway to enhance feedback and improve program direction with an information evaluation program. This program task will systematically identify issues and audiences, evaluate the existing products in relation to the issues and audiences, and then suggest ways to focus future resources and efforts.

As shown below, the TMP maintains an inventory of printed products that are available in limited quantities on request at no cost. TMP factsheets are 
continually developed and updated to ensure that current information about DOE transportation is always available and responsive to the needs of audiences. Plans are underway for development of new TMP products and activities. Information on obtaining products can be found in the Appendix.

\section{Information Products Inventory}

Factsheets:

- Radioactive Material Shipping Regulations

- Spent Fuel Transportation

- Radioactive Materials Transportation Emergency Response

- Transportation in the Nuclear Fuel Cycle

- Transporting Uranium Hexafluoride

- Training Programs for the Safe Transportation of Hazardous Materials

- The Transportation of Radioactive Materials - A Safe Record

- Risk in Transportation of Radioactive Material

- International Transportation of Radioactive Material

- Radioactive Material Shipments for Medicine and Industry

- Transporting Petroleum for Our National Security

- TRANSCOM - A Transportation Tracking and Communications System

- Transporting Low-Level Waste

- Highway Routing of Radioactive Materials

- Preparing Radioactive Materials Packagings for Shipment

- What Radioactive Materials Package Testing Is All About

Booklets and Reports:

- "Shipment of Radioactive Material by the U.S. Department of Energy"

- "Transporting Radioactive Material...Answers to Your Questions"

- "Guide to Documents on the Safe Transport of Radioactive Materials in Regular Freight Trains"

- "Emergency Response for Transportation Incidents Involving Radioactive Materials" 
Films/Videotapes:

- "Transportation of Radioactive and Other Hazardous Materials"

- "Highway Shipment of Spent Fuel"

- "Hazardous Materials Awareness - Emergency Response to a Rail Incident"

\section{Exhibits:}

- "Transporting Radioactive Material...Did You Know?"

- "TRANSCOM - Transportation Tracking and Communications System"

- "Safety is No Accident"

- "Full-Scale Cask Mock-Up"

New Products and Activities Under Development

- Public Information Booklet on Emergency Preparedness

- Film on Emergency Preparedness

- Film Documenting TRANSAX-90 Emergency Response Exercise

- Evaluation Program on Information Products

- Student Information Program

\section{Updates of Factsheets}

- Radioactive Material Shipping Regulations

- Spent Fuel Transportation

- Transportation Uranium Hexafluoride

- Training Programs for the Safe Transportation of Hazardous Materials

- The Transportation of Radioactive Materials - A Safe Record

- Risk in Transportation of Radioactive Material 


\subsection{CONCLUSION}

As shown in Figure 4, the Transportation Outreach Program Plan provides a structure for proactive planning to ensure that outreach is conducted in a timely manner and that the affected parties have an opportunity to participate in the decision-making process. The TMP's Outreach Program is developing in response to changes in DOE organization, policies, and management philosophies associated with waste storage, treatment and disposal, site cleanup and restoration, and modernization of the production complex. The Transportation Outreach Program Plan will be updated to reflect new activities and plans, as well as valuable insights gained from interacting with the public. It is expected that, as the program matures, more opportunities for participation will be provided and more products will be developed that are responsive to the needs of the public.

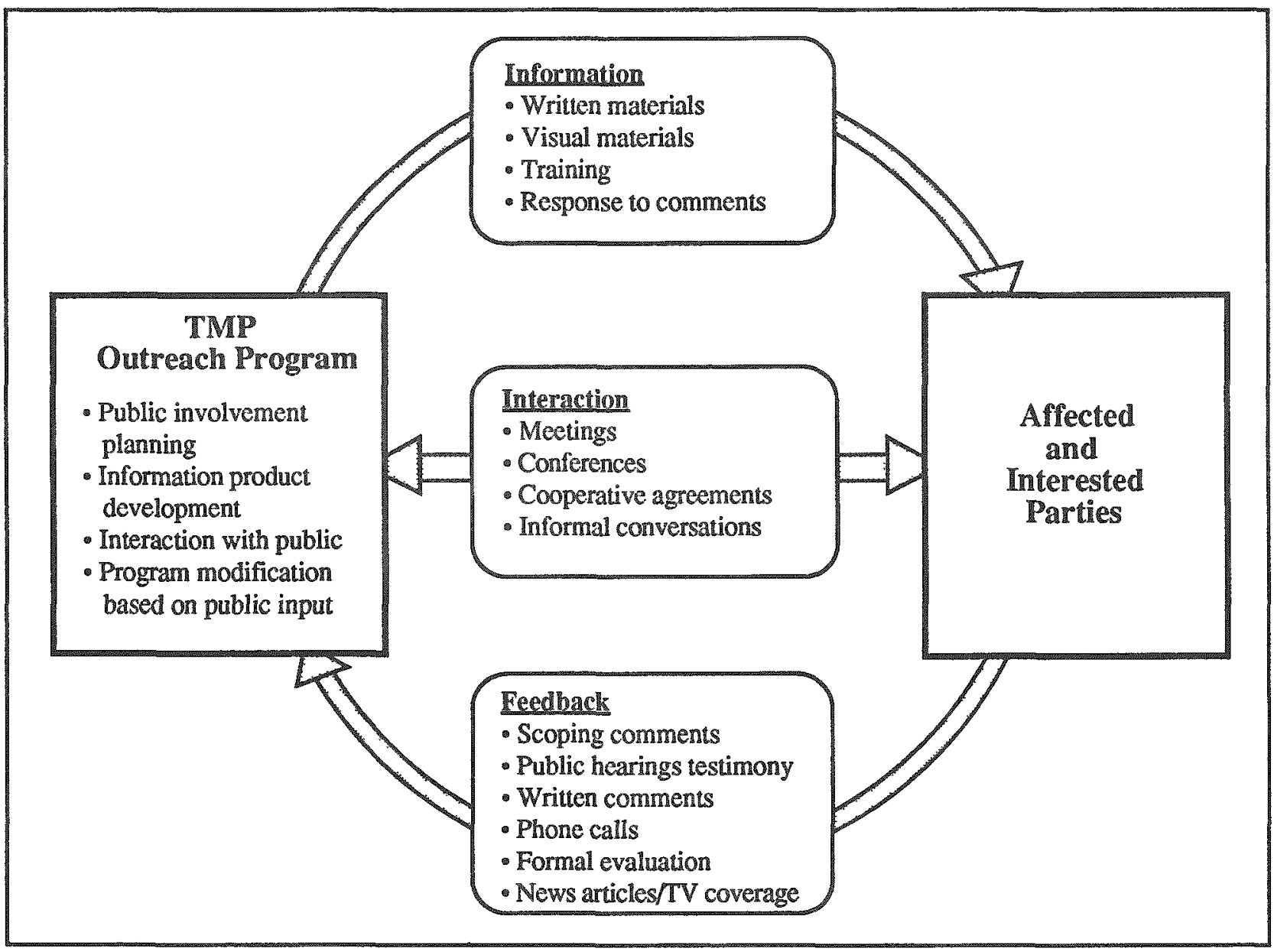

Figure 4. Successful Public Outreach and Involvement Requires a Two-Way Communication Process 


\section{APPENDIX \\ INFORMATION PRODUCTS CONTACTS}

To obtain copies of factsheets and booklets pertaining to DOE transportation, contact:

Transportation Information and Communications/

Resource Center (TIC-RC)

U.S. Department of Energy

EM 50.1, Trevion II

Washington, D.C. 20585-0002

Videos about DOE transportation for training or special group showings may also be obtained through the TIC-RC.

Other DOE programs may be contacted to obtain transportation-related information:

\section{- DOE Program Offices.}

Information pertaining to shipment and disposal of high-level radioactive waste and spent nuclear fuel may be obtained from:

Office of Civilian Radioactive Waste Management

Office of External Relations \& Policy Information Services Division

U.S. Department of Energy

Mail Stop RW-40

1000 Independence Avenue, S.W.

Washington, D.C. 20585

(202) $586-5722$

Information pertaining to transportation of materials related to decontamination and decommissioning at DOE sites may be obtained from:

Office of Nuclear Energy

U.S. Department of Energy

1000 Independence Avenue, S.W.

Washington, D.C. 20585

(202) $586-9096$ 


\section{- Site-Specific DOE Field Organizations =}

Albuquerque Operations Office

Office of Public Affairs

U.S. Department of Energy

P.O. Box 5400

Albuquerque, NM 87185

(505) 845-6938

Waste Isolation Pilot Plant Project Office

Office of Public Affairs

U.S. Department of Energy

P.O. Box 3090

Carlsbad, NM 88220

(505) $887-8117$

Chicago Operations Office

Office of Communications

U.S. Department of Energy

9800 South Cass Avenue

Argonne, IL 60439

(708) $972-2013$

Idaho Operations Office

Office of External Affairs

U.S. Department of Energy

785 DOE Place

Idaho Falls, ID 83401

(208) $526-1318$

Nevada Operations Office

Office of Public Affairs

U.S. Department of Energy

P.O. Box 14100

Las Vegas, NV 89114-4100

(702) 295-3521

Yucca Mountain Site Characterization

Project Office

Office of External Affairs

P.O. Box 98608

Las Vegas, NV 89193

(702) 794-7964
Oak Ridge Operations Office

Office of Public Affairs

U.S. Department of Energy

P.O. Box 2001

Oak Ridge, TN 37831

(615) 576-0885

Richland Operations Office

Office of Communications

U.S. Department of Energy

$825 \mathrm{Jadwin}$ Avenue

Richland, WA 99352

(509) 376-7378

San Francisco Operations Office Information Services and External Affairs U.S. Department of Energy

1333 Broadway

Oakland, CA 94612

(415) 273-7829

Savannah River Operations Office Office of External Affairs

U.S. Department of Energy

P.O. Box A

Aiken, SC 29808

(803) 725-2889 